Trakya Eğitim Dergisi

Cilt 10, Sayı 1

Ocak 2020, 151-168

Gelis Tarihi: 09.09.2019

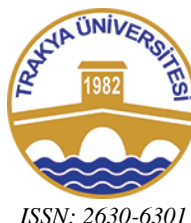

ISSN: $2630-6301$
Trakya Journal of Education

Volume 10, Issue 1

January 2020, 151-168

\title{
Algılanan Müdür Yönetim Tarzı ve İçsel Motivasyonun Öğretmenlerin Örgütsel Bağlılığına Etkisi
}

\section{The Effect of Principal Management Style and Intrinsic Motivation on Teachers' Organizational Commitment}

\author{
Seyfettin ABDURREZZAK ${ }^{1}$, Mehmet ÜSTÜNER ${ }^{2}$
}

\begin{abstract}
Öz: Bu çalışmanın amacı, öğretmen algılarına göre müdür yönetim tarzı ve içsel motivasyonun örgütsel bağlılık ile ilişkisini betimlemektir. Araştırmanın çalışma grubunu 2018-2019 öğretim yılı Edirne ili Uzunköprü ilçesinde yer alan 26 resmi okulda görevli 480 öğretmen oluşturmuştur. Veri toplama aracında "Algılanan Müdür Yönetim Tarzı Ölçeği”, "İçsel Motivasyon Ölçeği” ve "Öğretmenler için Örgütsel Bağlılık Ölçeği”" yer almıştır. Araştırmada öğretmenlerin işbirlikli müdür yönetim tarzı alg1 düzeyinin oldukça yüksek, otoriter müdür yönetim tarzı düşük, ilgisiz ve karşı koyucu müdür yönetim tarzı alg1 düzeyinin ise oldukça düşük, içsel motivasyon algı düzeyinin oldukça yüksek ve örgütsel bağlılık algı düzeyinin yüksek olduğu görülmüştür. Araştırmada cinsiyet ve branş değişkenine göre anlamlı farklılık olduğu, kıdem değişkenine göre anlamlı farklılık olmadığı, algılanan işbirlikli, otoriter, ilgisiz, karşı koyucu müdür yönetim tarzı ve içsel motivasyonun örgütsel bağlılığının anlamlı bir yordayıcısı olduğu belirlenmiştir.
\end{abstract}

Anahtar sözcükler: Yönetim tarzı, motivasyon, içsel motivasyon, örgütsel bă̆lılık.

\begin{abstract}
In this research, it is aimed to describe the relationship between perceived principal management style, intrinsic motivation and organizational commitment according to perceptions of teachers. The study group of the research; In 2018-2019 education year, all of 480 teachers working in 26 schools in Uzunköprü district of Edirne province was formed. In the data collection tool which consist of "Perceived School Principal Management Style Scale" "Intrinsic Motivation Scale" and "Teacher Organizational Commitment Scale". Results showed that teachers' perceptions of the perceived cooparetive management style was high level, authoritarian was low level, indifferent and resistant style were fairly low level, intrinsic motivation and organizational commitment was high level. Teachers' perception of perceived principal management styles, intrinsic motivation and organizational commitment union identification scores not different significantly in terms of professional seniority, but genderand and branch. Correlational analysis results showed that teachers' perceived cooperative, authoritarian, indifferent, resistant manager management styles and intrinsic motivation were found to be a significant predictor of their organizational commitment.
\end{abstract}

Keywords: Management style, motivation, intrinsic motivation, organizational commitment.

\section{Cite this article as:}

Abdurrezzak, S. \& Üstüner, M. (2020). Algılanan müdür yönetim tarzı ve içsel motivasyonun öğretmenlerin örgütsel bağl1lığına etkisi. Trakya Ĕ̈itim Dergisi, 10(1), 151-168.

\section{EXTENDED ABSTRACT}

\section{Background}

In general, the management styles exhibited by school principals can be classified as democratic, authoritarian, cooperative, resistant, obstructive, indifferent and obedient (Üstüner, 2016). Today, that the change is experienced rapidly, the responsibilities of the school principal and the competencies that they should have vary from day to day (Hallinger, 2005). Accordingly, it can be said that the main duties of school principals are to determine the tasks and areas of responsibility in the school, to support trust and cooperation among teachers and to provide instructional guidance (Supovitz et al., 2010). It is known that teachers' motivations, abilities and working environments have a direct effect on school and classroom practices. It is also known that leadership styles play an important role

\footnotetext{
${ }^{1}$ Öğretmen, Milli Eğitim Bakanlığı, srezzak@ hotmail.com, ORCID: 0000-0001-9892-7506

2 Prof.Dr., İnönü Üniversitesi, mehmet.ustuner@inonu.edu.tr, ORCID: 0000-0002-1724-8825
} 
in teachers' motivation (Eyal \& Roth, 2011). Studies conducted in the literature show that leaders play an important role in increasing the organizational commitment of employees (Balay, 2014, p.90). In this study, it was aimed to how teachers' commitment to school was influenced by the management style of the principal and their intrinsic motivation.

\section{Purpose}

In this research, it is aimed to describe the relationship between perceived principal management style, intrinsic motivation and organizational commitment according to the perceptions of teachers. In this study, the relationship between perceived principal management style, intrinsic motivation and organizational commitment is investigated.

\section{Method}

This research is a descriptive study based on the screening model which describes the perception level of teachers' perceived principal management style, intrinsic motivation and organizational commitment.

In the study, causal comparative design was used to determine whether teachers' perceptions of perceived principal management style, intrinsic motivation and organizational commitment differed significantly according to gender, seniority, and branches.

In addition, it is a correlational research examining the relationship between teachers' perceived principal management style, intrinsic motivation and organizational commitment.

The study group of the research are formed from 480 teachers working 2018-2019 education year, in public 26 schools in the center of Uzunköprü district of Edirne province. Analyzes are made on 391 data sets suitable for processing. In the first part of the data collection tool which consists of two parts, personal information in which participants' demographics are included; "Perceived School Principal Management Styles Scale" developed by Üstüner (2016) in the second section; " Intrinsic Motivation Scale " developed by Dündar, Özutku and Taşpınar (2007) "Teachers' Organizational Commitment Scale" developed by Üstüner (2009). SPSS 18 package program is used to analyze the data. Descriptive statistics, t-test, one-way analysis of variance and regression analysis are used to analyze the gathered data.

\section{Findings}

The perceived cooperative principals' perceptions of the management style of the teachers were quite high, the average of the authoritarian principals' perceptions of the management style was low, the average of the indifferent and resistant principals' perceptions of the management style was quite low. According to this finding, it can be said that teachers perceive the cooperative principal management style more positively than the authoritarian, indifferent and resistant management style. In the study, it was seen that the average level of intrinsic motivation perception of teachers was quite high and the average level of perception of organizational commitment was high.

It was observed that the perceived principals 'management style and sub-dimensions of perceived cooperative, authoritarian, indifferent and resistant management styles and organizational commitment perception levels did not show a significant difference according to the gender variable, but the teachers' intrinsic motivation perception level showed a significant difference according to gender. It was found that perceived principal management style, cooperative, authoritarian and resistant principal management styles sub-dimensions and intrinsic motivation and organizational commitment perception levels did not show a significant difference according to the branch variable, but only the indifferent principal management style sub-dimension showed a significant difference according to the branch variable.

There was no significant difference between teachers' perceived principal management style, cooperative, authoritarian, indifferent and resistant sub-dimensions, perceptions of intrinsic motivation, level of perception of organizational commitment and level of perception of organizational commitment. There is a positive and moderate relationship between perceived cooperative principal management style and teachers' organizational commitment; It has been found that there is a negative and low level relationship between perceived authoritarian, indifferent and resistant principal management styles and organizational commitment of teachers. It was understood that there was a 
positive and moderate relationship between intrinsic motivation and organizational commitment of teachers. The perceived cooperative, authoritarian, indifferent, resistant principal management style and intrinsic motivation give a low and meaningful relationship with teachers' organizational commitment. Perceived cooperative, authoritarian, indifferent, resistant principal management style and intrinsic motivation perceptions together account for $21 \%$ of the total variance of organizational commitment. Perceived cooperative, authoritarian, indifferent, resistant principal management style and intrinsic motivation the relative importance order of variables on organizational commitment, perceived cooperative principal management style, intrinsic motivation, perceived indifferent principal management style, perceived authoritarian principal management style and perceived resistant principal management style are faded.

\section{Discussion and Conclusion}

Teachers' cooperative principal management style perception level is quite high, authoritarian principal management style perception level is low, indifferent and resistant principal management style perception level is quite low level is also seen in the studies conducted in the literature (Argon \& Dilekçi, 2014; Özdemir, Kartal \&Yirci, 2014; Terzi \& Kurt, 2005).

In the study, it is understood that the level of intrinsic motivation perception of teachers is quite high and similar to some study results in the literature (Argon \& Ertürk, 2013; Özdemir et al., 2014; Tulunay Ateş, 2014).

It is understood that the perception level of teachers' commitment to school is high level in the study is similar to the results of some studies in the literature (Bogler \& Somech, 2004; Karataş \& Güleş, 2010; Tsui \& Cheng, 1999; Tulunay Ateş, 2014).

Results also indicated that teachers' perception of perceived principal management styles, intrinsic motivation and organizational commitment union identification scores not differed significantly in terms of gender and professional seniority, but branch.

In this study, it is understood that there is a positive and moderate significant relationship between perceived cooperative principal management style and organizational commitment of teachers is similar to the results of some studies in the literature (Hoy, Tartar \& Bliss, 1990; Özdemir, 2012; Somech \& Bogler, 2002; Terzi \& Kurt, 2005; Yuen, 1991).

The perceived authoritarian principal management style and the organizational commitment of the teachers; The finding that there is a negative and low level relationship between perceived indifferent principal management style and teachers 'organizational commitment and perceived resistant principal management style and teachers' organizational commitment is similar to that of Buluç (2009).

Another finding of the study is that there is a positive and moderate significant relationship between intrinsic motivation of teachers and organizational commitment is similar to some studies in the literature (Ağca \& Ertan, 2008; Buluç, 2009; Caldwell, Chatman \& O'Reilly, 1990; Kuavaas, 2006; Memişoğlu \& Kalay, 2017; Moon, 2000).

In the study, it was seen that there was a low and significant relationship between the perceived cooperative, authoritarian, indifferent, resistant principal management style and intrinsic motivation and teachers' organizational commitment.

In particular, perceived cooperative principal management style and intrinsic motivation were found to be an important predictor of organizational commitment, and perceived authoritarian, indifferent and resistant principal management styles did not have a significant effect.

According to the findings, it may be suggested that in order to increase the commitment of teachers to school, principals should avoid authoritarian, indifferent and resistant behaviors and practices in the managerial behaviors and practices of the school, and on the contrary, they should promote cooperation. 


\section{GíRIŞ}

Literatürde sorunlarla başa çıkmak olarak tanımlanan yönetim (Robbins ve Judge, 2013, s.376), örgütün amaçlarına ulaşabilmesi için eldeki mevcut tüm kaynakları ve imkânları en iyi biçimde kullanma bilimidir (Erdoğan, 2014, s.8). Toplumun eğitim ihtiyacını karşılamak için kurulmuş eğitim örgütlerini amaçları doğrultusunda etkili işletmek ve yenileştirmek (Başaran, 1996, s.12) için madde ve insan kaynaklarını kullanmadan birinci derecede sorumlu olan yöneticisinin (Aydın, 2010, s.328) öncelikli amac1, hali hazırda var olanlardan daha fazlasını okuluna katabilmek olmalıdır. Bu amac1 yerine getirmeye çalışan okul yöneticisi, okulun sahip olduğu tüm kaynaklardan faydalanmaya çalışmalıdır (Koontz, 1968; akt. Taymaz, 2011, s.57).

Değişimin hızlı yaşandığı günümüzde okul yöneticisinin sorumlulukları ile sahip olması gereken yeterlikler de günden güne değişim göstermektedir (Hallinger, 2005). Okuldaki çalışanların görev ve sorumluluk alanlarını belirleme, öğretmenler arasında güven duygusunu ve işbirliğini destekleme, öğretimsel rehberlik yapma okul müdürlerinin temel görevleri (Supovitz, Sirinides ve May, 2010) arasında sayılmaktadır. Bunun yanı sıra okul amaçlarının, ihtiyaçlarının, politikasının iç ve dış paydaşlar ile paylaşılması (Uğurlu, Beycioğlu ve Özer, 2011). okulun amaç ve ihtiyaçlarının belirlenmesi, öncelikli görülen işlerin tasarlanması, eylem planının uygulanması ve okul bütçesinin hazırlanması okul yöneticilerinin görevleri içinde yer alır (Bush, 2007). Okul yöneticisinin öncelikli görevi, okulun var olan amaçlar doğrultusunda sürekliliğini sağlamaktır. Bu bakımdan okulun yönetiminin önemli görülmesi okul müdürünün okuldaki yetki ve sorumluluklarını da tanımlamaktadır (Bursalığlu, 2005, s.6).

Bireyleri örgütsel amaçları gerçekleştirecek davranışları göstermeye zorlayan bir güç olarak yetki (Taymaz, 2011, s.58) çalışanları etkileme, harekete geçirme ve emir verme hakk1 olarak ifade edilmiştir (Bursalığlu, 2005, s.182; Şişman ve Turan, 2005, s.110). Bu yetkinin kaynağını sadece yasalar oluşturmaz. Okul yöneticisinin yetkisini onun kişilik, uzmanlık bilgisi (Şişman ve Turan, 2005, s.110) içinde yetiştiği aile, eğitimi, çevresel kültürü ve toplumun değer yargıları da etkiler. Bu bileşenlerin etkileşimi ile ortaya çıkan yönetim tarzı (Arıŏlu, 2006) müdürün okulda yönlendirdiği insanlar hakkındaki fikirleri, bireysel özellikleri, okulun mevcut yapısı ve amaçları, çalışanların özellikleri ile zaman gibi etkenlerin ortak etkisinin bir sonucudur (Üstüner, 2016).

\subsection{Algılanan Müdür Yönetim Tarzı}

Yöneticinin sahip olduğu yetkiyi kullanış biçimi, onun yönetim tarzını belirleyen en önemli unsurdur (Terzi ve Kurt, 2005). Genel olarak okul müdürlerinin sergiledikleri yönetim tarzları demokratik, otoriter, işbirlikli, karşı koyucu, engelleyici, ilgisiz ve boyun eğici olarak sınıflandırılabilir (Üstüner, 2016).

Demokratik yönetici, karar verme sürecinde astlarına katılma olanağı veren, işbirliği yapmayı isteyen, adil ve rasyonel yöntemler izleyen kişiler olarak tanımlamaktadır (Bursalığlu, 2005). Örgütteki insanların şahsi ihtiyaç ve isteklerini en iyi biçimde yerine getiren ve hedeflerine ulaştıran örgütün yönetimidir (Erdoğan, 2014, s.40). Demokratik müdür, farklı görüşlere saygılı, adaletli, yeniliklere karşı açı görüşlü biri olarak (Gül ve Saraç, 2018) okulundaki öğretmenlerin yönetimsel uygulamalara katılımını önemli görmektedir (Zel, 2001).

Otoriter yönetici, okulun amaçlarına göre gerekli düzenlemeleri yapan fakat bunları yaparken çalışanların ilgi, istek, ihtiyaçları önemsemeyen ve çalışanların çalışma ortamındaki huzur ve mutluluğunu sağlayacak hiçbir önleme başvurmayan yöneticilerdir (Erdoğan, 2014, s.40). Bu tarzda yönetim anlayışı olan okul müdürlerinin, okul kurallarının belirlenmesinde öğretmenleri karara katmadıkları, ödül vermek yerine korkutma ve cezayı kullandıkları, kişilerarası ilişkilerinde resmi ast üst ilişkisine göre davrandıkları, makamın gücünü sıklıkla kullandıkları, okulda verdiği emir ve görevlere her çalışan tarafından koşulsuz uyulmasını istedikleri için genel davranışlarında katı ve hoşgörüsüz oldukları söylenebilir (Üstüner, 2016).

İşbirlikli tarzda yönetsel davranış sergileyen okul müdürlerinin, okul ortamında karşıllaşılan sorunları öğretmenleriyle birlikte çözümler üretmeye çalıştıkları görülmüştür. Özellikle öğretmenlerinden yardım istemekten çekinmezler. Okulda öğretmenler arasında birlikteliği sağlayacak ve işbirliğini teşvik edecek davranışlarda bulunurlar. Öğretmenlerini takdir ederler ve onların yenilikleri takip etmelerini desteklerler (Üstüner, 2016). 
Karşı koyucu, engelleyici tarzdaki okul müdürleri, okulda kendi kurdukları düzenin bozulmasını istemezler. Okulda yeni bir şeyin uygulanmasına hemen karşı çıkarlar. Okulun işleyişinde resmi yetkinin dışına çıkmayarak, mevzuat hükümlerine uygun davranışlar gösterirler. Öğretmenlerle ilişkilerinde çatışmacı bir tutum sergileyerek, okulda yapılan işlerde okul müdürü olarak sadece kendilerinin ön planda olmasını isterler (Üstüner, 2016). Bu tarzdaki yöneticilerin öğretmenlere destek olmadıkları ve genel olarak öğretmenler tarafından yapılan çalışmalara da engel olmaya çalıştıkları söylenebilir.

İlgisiz tarzdaki yöneticiler ellerinde bulunan yetkileri kullanmazlar. Yöneticinin altında çalışanlar kendi sorunlarını kendileri çözmeye çalışarak, bireysel amaçlarını da kendileri belirlerler. Bir durum hakkında yöneticiye başvurulduğu zaman sadece görüşünü belirtir ve eğer gerekirse kaynak kişi ya da araç gereç sağlamaya çalışırlar (Erdoğan, 2014, s.39). Okulda yaşanan sorunlara ilgisiz davranma, sorunları görmezden gelme, çalışanlar arasında adil olamama, okulda olup bitenleri merak etmeyerek sorunların çözümünde sürekli erteleme eğilimi gösterme gibi davranışlar bu tarzdaki okul müdürlerinin sergiledikleri olası davranışlar olarak görülmektedir (Üstüner, 2016).

Boyun eğici tarzdaki okul müdürleri için ise, kendilerine ait fikirlerden ziyade başkalarının söyledikleri daha önemlidir. Bu tarzdaki yöneticiler olaylar karşısında çabuk karar veremezler. Etrafındaki insanlardan çok çabuk etkilenirler ve genellikle güçlü olan grup üyelerinin yanında yerini alırlar. Okulda her kesime karşı iyi görünmeye çalışırlar ve düşüncelerini açıkça ifade etmeyerek olaylar karşısında genelde sessiz ve pasif kalırlar (Üstüner, 2016).

\section{2. İçsel Motivasyon}

Okulların sahip olduğu insan ve madde kaynaklarının verimli yönetimi için okul müdürlerinden etkili yönetimsel davranışlar sergilemeleri beklenmektedir (Gülcan, 2012). Okulun amaçlarının gerçekleştirilmesi ve olumlu okul havasının oluşturulması okul müdürün sorumluluğundadır. Aslında formal yetkilerden güç alan okul müdürü, astları tarafından benimsenir ve kabul görürse işgörenleri okulun amaçları doğrultusunda etkiler ve yönlendirebilir (Bursalığlu, 2005, s.40). Bu bağlamda okulun doğru yönetilmesi için uğraşan okul müdürleri, okulun var olan amaçlarını gerçekleştirmeye çaba sarf ederken, diğer yandan öğretmenlerin beklentilerini karşlayarak onların güdülenmelerini desteklemelidir (Y1lmaz ve Ceylan, 2011).

Motive olmak, bir şeyler yapmak için hareketlenmek, harekete geçmektir (Ryan ve Deci, 2000). Bir başka tanımda motivasyon, harekete geçiren, yönlendiren ve devam ettiren kuvvet (Steers ve Perter, 1991; akt. Riggio, 2016, s.189) olarak tanımlanmıştır. Kökeni İngilizce ve Fransızca bir kelime olan 'motivation' kelimesinden türetilmiş olan motivasyon, Türk Dil Kurumu [TDK] (2018) sözlügünde, isteklendirme, güdüleme anlamına gelmektedir. Bir hedefe ulaşmak için gösterilen çabaya yönelik odaklanma, yön ve istikrarlı durum (Robbins ve Judge, 2013, s.204) olarak da ifade edilen motivasyon, insanın gerçekleştirdiği eyleminin sonunda elde edeceği güzel bir şeye inanmasının bir sonucudur (Eyal ve Roth, 2011). Motivasyon, bireyde davranışı uyaran ve onu örgütün fayda göreceği doğrultuda yönlendiren (Miner, 2008; akt. Lunenburg ve Ornstein, 2013, s.80) tutarlı ve azimli davranışlardır (Robbins ve Judge, 2013, s.205). İnsanı harekete geçirir, hedefler doğrultusunda davranışları yönlendirir ve bu hedeflere ulaşana kadar davranışların devamlılığını sağlar (Steers, Mowday ve Shapiro, 2004).

Motivasyon içsel ve dişsal motivasyon olarak sınıflandırılabilir. Bunlar arasındaki en belirgin fark ise, bireyin eyleme geçmedeki mantı̆̆ıdır. İçsel motivasyonda yapılan iş birey için bir ödül anlamındayken, dişsal motivasyonda dış kaynaklı bir etki söz konusudur (Hoy ve Miskel, 2012, s.157). İçsel motivasyonda uğraşın kendisi kişiye ilginç geldiği için kişi bu uğraşı yapmaya isteklidir (Deci, Coestner ve Ryan, 1999; Ryan ve Deci, 2000). Yani bir şeyi yapmak zorunluluğunda olunmasa bile, o şeyi yapmak için bireyi harekete geçiren şey içsel motivasyondur (Raffini, 1996; akt. Hoy ve Miskel, 2012, s.157). Birey içsel olarak motive edildiğinde, dış kaynaklı herhangi bir şey için değil kendini bu işte kanıtlamak için harekete geçer. Tamamen kendi iradesiyle işin sonunda maddi ödül ya da herhangi bir şey olmadığını bilerek görevini yerine getirir (Amabile, 1985; Deci ve Ryan, 1985). Bu görevi gerçekleştirmekten doğan memnuniyet ve duyulan haz motivasyonun kendi ödülünü oluşturur (Deci ve diğerleri, 1999). Bu bakımdan bütün zorluklara rağmen kişisel ilgileri öğrenme sürecindeki doğal bir eğilim olduğu düşünülen içsel motivasyon (Deci ve Ryan, 1985), insanın doğası gereği öğrenme ve öğrendiklerini özümseme eğilimini yansıtan önemli bir yapıdır (Ryan ve Deci, 2000). İçsel motivasyon gücünü yeni şeyler öğrenme ve yaratma arzusundan almaktadır (Deci ve diğerleri, 1999). Bu bağlamda 
öğrenmeye duyulan ilgi, merak ve başarmanın verdiği haz gibi içsel faktörler bireyin davranışlarını yönlendirebilmektedir (Deci ve Ryan, 1985; Vallerand, Pelletier, Blais, Senecal ve Vallieres, 1992). Bu durum zamanla birey tarafından sıklıkla tekrar eden davranış halini almaktadır (Deci, Vallerand, Pelletier ve Ryan, 1991).

\section{3. Örgütsel Bağgılık}

İşgörenin içsel olarak motive olmasında kendisini çalıştığı kuruma bağlı hissetmesinin önemli olduğu bilinmektedir. Örgüt üyeleri çalıştıkları örgütten etkilenirlerken, aynı zamanda örgütsel üyeliklerini devam ettirmek için içten bir çaba sarf ederler (Aydın, 2013, s.73). Bu çabanın bir ürünü olan bağlılık kavramı, duyuşsal bağl11ık (Buchanan, 1974), örgütsel kimlik veya örgütsel katılım gibi kavramlar şeklinde literatürde yerini almıştır (Hall ve Schneider, 1972; akt. Angle ve Perry, 1981). 1970'li yılların başından itibaren örgütsel davranış konusunu anlamaya yönelik yapılan araştırmalara konu edilen örgütsel bağl1lık kavramının önemli bir değişken olduğu görülmüştür (Staw ve Ross, 1978). Başlangıçta bireyin kurumuna karşı duyuşsal hissiyatı olarak görülen bağlılığın bu ilgiyi nereden aldığına ilişkin birkaç olası sebep vardır. Bunlardan birincisi çalışanın samimiyeti, ikincisi sadakati ve üçüncüsü de giderek artan uyumudur (Cook ve Wall, 1980; Mowday, Steers ve Porter, 1979).

Örgütsel bağlılık, örgütsel amaçları gerçekleştirmeye yönelik harcanan çaba (Sheldon, 1971), örgüte karşı aidiyet ve sadakat (Kantor, 1968; Lee, 1971), ücret, statü, ya da daha büyük bir sosyal çevreye sahip olmak için örgütten ayrılmama isteği (Hrebiniak ve Allutto, 1973) olarak tanımlanmaktadır (akt. Buchanan, 1974). Örgütsel bağlılık, bireyin örgüte karşı psikolojik bakımdan hissettiği bir durum olup, bireyin örgütsel özellikleri tümüyle benimsemesidir (Allen ve Meyer, 1990; O’Reilly ve Chatman, 1986). Bireyin örgütle olan ilişkisini düzenleyen örgütsel bağlılık, çalışanın örgüt amaçlarını benimsemesi ve örgütteki mevcut konumunu sürdürmek için çaba göstermesidir. Örgütün amaçlarına ve başarıya ulaşması için birey ile örgütün uyumunu sağlayan karşılıklı ilişkidir (Meyer ve Allen, 1991; Morrow, 1983).

Porter, Steers, Mowday ve Boulian (1974), bağlılı̆̆ın bireyin örgütteki devamlılığını sağlayan bir güç olduğunu, bu gücün kaynağını ise bireyin örgütsel amaçlara olan inancından, örgüt için çalışma ve bireyin örgüt üyeliğini devam ettirme isteğinden aldığını ifade etmişlerdir. Burada ifade edildiği gibi örgütsel bağll1ığın üç boyutu bireyin örgütüne güvenmesi, çalışma ve üyeliğini sürdürme istekliliğidir. Bu boyutları Eisenberg, Monge ve Miller (1983) özdeşleşme, kabul ve isteklilik, O'Relly ve Chatman (1986), uyum, özdeşleşme ve içselleştirme, Allen ve Meyer (1990), duygusal, devam ve normatif, Buchanan (1974) ise, özdeşleşme, katılım ve sevgi olarak adlandırmışlardır.

Örgüte bağlll1k hisseden birey, örgüt üyeliğini sürdürme konusundaki arzusu, örgüt için gayret gösterme isteği ve örgütün amaçlarına olan inancı sayesinde kişisel verimliliğini artırıcı yenilikçi davranışlar sergiler (Angle ve Perry, 1981). Yani örgüte karşı bağl1lık hisseden birey örgütsel hedeflere ulaşmak için işlerinde daha fazla çaba harcaması olağan bir durumdur (Yousef, 2000). Bağlılık sayesinde birey halihazırdaki konumunun kendisi için iyi bir durum olduğunu hisseder (Bateman ve Strasser, 1984). Bu sayede örgütün amaç ve değerlerine daha güçlü inanır ve örgütsel üyeliğini devam ettirme isteği artar (Kanter, 1968).

Yöneticilerin örgüt ortamındaki yönetimsel eylemlerini düzenlemeleri açısından işgörenlerin örgütsel bağlılıklarını neyin artırdığını bilmeleri önemlidir. Bu konu okul örgütleri olduğunda bunun önemi daha da artmaktadır. Eğitim sisteminin önemli yapıları olan okulların, amaçlarını gerçekleştirmek için yüksek düzeyde motive olmuş ve okula bağllık hisseden üyelere ihtiyacı vardır (Üstüner, 2009). Çünkü varlığının nedeni eğitim hizmetini üretmek olan okullarda, kuşkusuz sistemin vazgeçilmez ve stratejik parçası öğretmenlerdir (Başaran, 1996, s.123; Bursalıoğlu, 2005, s.42). Öğretmenlerden okullarının amaçlarını gerçekleştirmek için çabalayan ve bağlılık gösteren bireyler olmaları beklenmektedir (Somech ve Bogler, 2002). Bu bakımdan okulun amaç ve değerlerinin benimsenmesi ile devamlılık (Celep, 2000, s.138), okul işlerinin niteliği, özerklik, okul kararlarına katılım, çalışanlarla işbirliği, kişisel gelişim ve kurumsal kaynaklar okuldaki öğretmen bağlılı̆̆ını artıran önemli etkenlerdir. Öğretmenlerin çabalarının başarıyla sonuçlanması işlerine, okuluna ve öğrencilerine olan bağlılıklarını da artırmaktadır (Firestone ve Pennell, 1993).

\subsection{Algılanan Müdür Yönetim Tarzı ve İçsel Motivasyon ile Örgütsel Bağlılık Arasındaki İlişki}

Liderin takipçileri üzerinde etkili olabilmesi, onları neyin motive ettiğini çok iyi bilmesine ve liderin de bu etkenlerle uyumlu olmasına bağlıdır (Argyris, 1976; Maslow, 1954). Örgütün hedeflerine 
ulaşabilmesinde motivasyon liderlerin elinde güçlü bir yönetim aracı olarak kullanılmaktadır. Mehta ve arkadaşları (2003), destekleyici ve yönlendirici liderlik tarzlarının çalışanları daha fazla motive ettiğini, Bass ve Avolio (1999), dönüşümcü liderlik tarzı ve motivasyon arasında ilişki olduğunu, Storseth (2004) ise, insanı önemseyen liderlik tarzının motivasyon için önemli bir yordayıcı olduğunu ifade etmişlerdir (akt. Buble, Juras ve Matić, 2014).

Öğretmenlerin motivasyonlarının, yeteneklerinin ve çalışma ortamlarının okul ve sınıf uygulamaları üzerinde doğrudan bir etkisi vardır. Okul yöneticilerinin öğretmenlerin motivasyonu aracılığıyla bu etkiyi gerçekleştirdikleri (Leithwood ve Jantzi, 2006) ve sergiledikleri liderlik tarzlarının öğretmenlerin motivasyonunda önemli bir rolü olduğu bilinmektedir (Eyal ve Roth, 2011), Literatürde okul müdürlerinin okul liderliği davranış ve uygulamaları ile öğretmen motivasyonuna ilişkin (Alam ve Farid, 2011; Brown-Howard, 2007; Cemaloğlu, 2002; Davis ve Wilson, 2000; Klassen Chong, Huan, Wong ve Hannok, 2008; Leithwood ve Mascall, 2008; Özdemir, Kartal ve Yirci, 2014; Price, 2008; Reynolds, 2009; Sarı, Y1ldız ve Canoğulları, 2018; Thoonen, Sleegers, Oort, Peetsma ve Geijsel, 2011; Webb, 2007 ve Woolfolk Hoy, 2008) çalışmalar yer almaktadır. Aynı zamanda bağlılığın ve motivasyonun, kişinin davranışlarını etkilemek için nasıl bir arada kullanıldığını incelemeye yönelik çalışmalar yapılmıştır (Meyer, Becker ve Vandenberghe, 2004). Ayrıca örgüte duygusal bağl1lığın motivasyonel temelleri (Eby, Freeman, Rush ve Lance, 1999) ile örgütsel bağl1lik ve motivasyon ilişkisinin incelendiği (Ağca ve Ertan, 2008; Kuavaas, 2006; Moon, 2000; School, 1981) çalışmalar da mevcuttur.

Yönetici davranışları ile çalışanların örgütsel bağl1lı̆ına ilişkin yapılan araştırmalarda (Bateman ve Strasser, 1984; DeCotiis ve Summers, 1987, Mathieu ve Zajac, 1990) yöneticilerin benimsemiş olduğu yönetimsel davranışlar ile çalışanların örgütsel bağl1lığı arasında ilişki bulunmuştur (akt. Lok ve Crawford, 1999). Menzies (1995) ise, liderliğin öğretmenin örgütsel bağlılığındaki en etkili unsur olduğunu belirtmiş̧tir (Sun, 2004). Literatürde öğretmenlerin örgütsel bağl1lığının çeşitli değişkenler açısından incelendiği (Balay, 2000; Celep, 1998; Firestone ve Rosenblum, 1988; Firestone ve Pennell, 1993; Özden, 1997; Rosenholtz, 1989; Somech ve Bogler, 2002; Tsui ve Cheng, 1999 ve Üstüner, 2009) araştırmaların yanı sıra, okul müdürlerinin okul liderliği davranış ve uygulamaları ile öğretmenlerin örgütsel bağlılığını konu alan ilişkisel (Aydın, Sarıer ve Uysal, 2013; Buluç, 2009; Hulpia, Devos ve Keer, 2010; Okçu, 2014; Sun, 2004; Terzi ve Kurt, 2005; Uslu ve Beycioğlu, 2013 ve $\mathrm{Yu}$, Leithwood ve Jantzi, 2002) çalışmalar bulunmaktadır.

\subsection{Araştırmanın Amacı}

Literatürde çalışmalar liderlerin çalışanların örgütsel bağlılıklarını artırmada önemli rolü olduğunu göstermektedir (Balay, 2014, s.90). Bu araştırmanın amac1, öğretmenlerin algıllanan müdür yönetim tarzı, içsel motivasyonu ve örgütsel bağllığı algı düzeyleri arasındaki ilişkiyi betimlemektir. $\mathrm{Bu}$ amaçla öğretmenlerin algılanan müdür yönetim tarzı ve içsel motivasyonu onların örgütsel bağlılıklarını nasıl etkilemektedir? sorusu araştırmanın genel amacını oluşturmuştur. Bu amaç doğrultusunda aşağıdaki sorulara yanıt aranmıştır;

1. Öğretmenlerin müdür yönetim tarzı, içsel motivasyonu ve örgütsel bağl11ıklarına ilişkin algı düzeyleri nedir?

2. Öğretmenlerin müdür yönetim tarzı, içsel motivasyonu ve örgütsel bağlılıkları algı düzeyi onların cinsiyet, branş ve kıdemlerine göre anlamlı bir farklılık göstermekte midir?

3. Öğretmenlerin müdür yönetim tarzı ve içsel motivasyonu algı düzeyi onların örgütsel bağlılık algı düzeyini yordamakta mıdır?

$\mathrm{Bu}$ bağlamda, araştırma okul müdürlerinin okulun yönetiminde sergiledikleri yönetim tarzlarını, öğretmenlerin içsel motivasyonunu ve okula bağl1lı düzeyini, ayrıca bu değişkenler arasındaki ilişkiyi öğretmen görüşlerine göre betimlemesi ve alana sağlayacağı katkı bakımından önemli görülmektedir. 


\section{YÖNTEM}

\subsection{Araştırmanın Deseni}

Çalışma öncelikle öğretmenlerin algılanan müdür yönetim tarzı, içsel motivasyonu ve örgütsel bağl1lıklarını betimlemleyen tarama modeline dayalı betimsel çalışmadır. Tarama modeli var olan durumu olduğu gibi resmetmeyi esas alır. (Karasar, 2012). Çalışmada öğretmenlerin algılanan müdür yönetim tarzı, içsel motivasyon ve örgütsel bağlllıkları algılarının cinsiyet, kıdem, branşlarına göre farklılık olup olmadığının belirlenmesinde nedensel karşılaştırmalı desen kullanılmıştır. Bu desende bireyler ya da grupların birbirlerinden farklılaşma nedenleri ve bunların sonuçları birlikte ifade edilmektedir (Fraenkel, Wallen ve Hyun, 2012). Araştırma ayrıca öğretmenlerin algılanan müdür yönetim tarzı, içsel motivasyon ve örgütsel bağlılıkları arasındaki ilişkiyi inceleyen bir çalışmadır. İlişkisel araştırmalar iki veya daha fazla değişkenin birbiri ile ilişkisini araştırmaktadır (Fraenkel vd., 2012; Karasar, 2012). Yapılan bu araştırma ile algılanan müdür yönetim tarzı, içsel motivasyon ve örgütsel bağlılık arasındaki ilişkiler incelenmiştir.

\section{2. Çalışma Grubu}

Çalışma grubunu 2018-2019 öğretim y1lında Edirne ili Uzunköprü ilçesinde yer alan 26 resmi okulda görevli toplam 480 öğretmen oluşturmuştur. Öğretmenlerin tümüne ölçekler dağıtılmış ve 416 adet veri geri dönmüştür. Analizler işlemeye uygun 391 veri üzerinden yapılmıştır. Araştırmaya katılan öğretmenlerin demografik özellikleri Tablo'1 de gösterilmiştir.

Tablo 1. Öğretmenlerin demografik özelliklerine ilişkin frekans ve yüzde dağılımları

\begin{tabular}{|c|c|c|c|c|c|c|c|c|c|c|c|}
\hline Değişken & & $\mathrm{f}$ & $\%$ & Değişke & & $\mathrm{f}$ & $\%$ & Değişken & & $\mathrm{f}$ & $\%$ \\
\hline \multirow[t]{2}{*}{ Cinsiyet } & Kadın & 239 & 61,1 & & & & & Branş & $\begin{array}{l}\text { Okul Önc.ve } \\
\text { Sinıf }\end{array}$ & 145 & 37,1 \\
\hline & Erkek & 152 & 38,9 & & & & & & Branş & 246 & 62,9 \\
\hline \multirow[t]{3}{*}{ Yaş } & 28 ve alt1 & 47 & 12 & Kidem & $1-5$ y1l & 74 & 18,9 & \multirow{3}{*}{$\begin{array}{l}\text { Öğrenim } \\
\text { Durumu }\end{array}$} & Lisans & 349 & 89,3 \\
\hline & 29-33 yaş & 83 & 21,2 & & $6-10$ yil & 92 & 23,5 & & Yüksek Lisans & 40 & 10,2 \\
\hline & 34 ve üst & 261 & 66,8 & & 11 ve üst & 225 & 57,5 & & Doktora & 2 & 0,5 \\
\hline \multicolumn{6}{|l|}{ Toplam Ö } & 391 & 100 & & & & \\
\hline
\end{tabular}

Çalışma grubundaki öğretmenlerin 239'u (\%.61,1) kadın, 152'si (\%.38,9) erkektir. Yaşları, 28 yaş ve altı 47 (\% 12), 29 - 33 arası yaş $83(\% 21,2), 34$ yaş ve üzeri $261^{\prime}$ dir $(\% 66,8) .145^{\prime}$ i ( $\left.\% 37,1\right)$ okul öncesi ve sınıf öğretmeni iken 246's1 (\%62,9) branş öğretmenidir. Kıdem olarak 74'ü (\%18,9) 1-5 yıl. 92'si $(\% 23,5) 6-10$ yıl ve 225 'i $(\% 57,5) 11$ y1l ve üzerindedir. $349(\% .89,3)$ lisans, $40(\% 10,2)$ yüksek lisans ve $2(\% 0,5)$ doktora öğrenimi görmüştür.

\subsection{Veri Toplama Aracı}

2018-2019 öğretim yılında yapılan çalışmanın veri toplama aracı iki bölümden oluşmuştur. İlk kısımda öğretmenlerin kişisel bilgileri, diğer bölümde Üstüner (2016) tarafından geliştirilen "Algllanan Müdür Yönetim Tarzı Ölçeğì", Dündar, Özutku ve Taşpınar tarafından geliştirilen "İçsel Motivasyon Ölçeği " ve Üstüner (2009) tarafindan geliştirilen "Ögrretmenler için Örgütsel Bağlllık Ölçeği”" yer almıştır.

2.3.1. Algılanan Müdür Yönetim Tarzı Ölçeği: Üstüner (2016) tarafindan okul müdürlerinin kullandıkları yönetici tarzını betimlemek amacıyla geliştirilen dört faktörlü ölçeğin işbirlikli 7, otoriter 7, ilgisiz 7 ve karşı koyucu 4 madde olmak üzere dört faktörlü 25 maddeden oluşmaktadır. 5'li likert ölçeği (1) hiçbir zaman ve (5) her zaman biçimindedir. Dört faktörlü ölçekte açıklanan toplam varyans $\% 67,001$ 'dir. Ölçeğin güvenirliğine ilişkin Cronbach's Alpha değerleri işbirlikli .92, otoriter .89, ilgisiz .86 ve karş1 koyucu .85 olarak bulunmuştur. Bu çalışmada ise ölçeğin güvenirlik analizlerinde 
Cronbach's Alpha değerleri değerleri işbirlikli .87, otoriter .77, ilgisiz .76 ve karşı koyucu .70 olarak bulunmuştur.

2.3.2. İçsel Motivasyon Ölçeği: Dündar, Özutku ve Taşpınar (2007) tarafından geliştirilen ölçek 9 maddedden oluşmaktadır. 5'li likert ölçeği (1) motive etmez ve (5) çok motive eder biçimindedir. Tek faktörlü ölçeğin güvenirlik analizlerinde Cronbach's Alpha değeri .83 olarak bulunmuştur. Bu çalışmada ise ölçeğin güvenirlik analizlerinde Cronbach's Alpha değeri .85 olduğu bulunmuştur.

2.3.3. Öğretmenler için Örgütsel Bağllllk Ölçeği: Üstüner'in (2009) öğretmenlerin okula bağl1lıklarına ilişkin algılarını betimlemek amacıyla geliştirdiği ölçek 17 maddeden oluşmaktadır. Tek faktörlü. 5'li likert ölçeği (1) hiçbir zaman ve (5) her zaman biçimindedir. Ölçeğin açıkladığı toplam varyans \% 48,233 ve Cronbach's Alpha iç güvenirlik katsayısı .96 olarak bulunmuştur. Bu çalışmada ise ölçeğin güvenirlik analizlerinde Cronbach's Alpha değeri .95 olarak bulunmuştur.

Veri toplama aracı uygulama aşaması için düzenlendikten sonra Edirne Valiliği Edirne il Milli Eğitim Müdürlüğünden uygulama izin onayı alınmıştır. Veri toplama aracının okullara dağıtılması ve yönergelere uygun biçimde uygulanması araştırmacılar tarafından gerçekleştirilmiştir. Uygulama sırasında katılımcılara ölçek hakkında bilgi verilmiştir.

\subsection{Verilerin Analizi}

Çalışmada analizler yapılmadan önce veri setinin normallik varsayımı parametrelerini sağlayıp sağlamadığ incelenmiştir. Bu amaçla 416 adet olan veri seti üzerinden yapılan uç değer analizinde 25 tanesi silinmiştir. Bu veri setinin normal dağılımda olup olmadığı anlamak için çarpıklık ve basıklık değerlerinin “ \pm 2 ” (Cameron, 2004; akt. Demirtaş, Özer, Atik ve Kırbaç, 2015) arasında olup olmadığına bakılmış ve veri seti için çarpıklık ve basıklık değerlerinin $+1,24 /-1,10$ arasında olduğu ve buna bağl1 olarak normallik varsayımını sağladığı anlaşılmıştır. Analizler işlemeye uygun 391 veri üzerinden yapılmıştır. Araştırmada öncelikle betimsel istatistik hesaplamaları yapılmıştır. Öğretmenlerin algılanan müdür yönetim tarzı, içsel motivasyon ve örgütsel bağlılığı algı düzeyini belirlemek için aritmetik ortalamalar tespit edilmiştir. Aritmetik ortalamalar yorumlanırken 1.00-1.79 oldukça düşük, 1.80-2.59 düşük, 2.60-3.39 orta, 3.40-4.19 yüksek ve 4.20-5.00 aralığ1 oldukça yüksek olarak belirlenmiştir. Cinsiyet ve branşlarına göre farklılık olup olmadığını tespit etmek için t-testi; çalışma sürelerine bağlı farklılık olup olmadığının belirlemek için tek yönlü varyans analizi yapılmıştır. Tek yönlü varyans analizi sonucu eğer anlamlı ise bu anlamlılığın hangi gruplar arasında olduğunu tespit etmek amaciyla Scheffe testi yapılmıştır. Korelasyonun yorumlanmasında 0.70-1.00 arasında ise yüksek, 0.70-0.30 aralığında orta düzey ve 0.30-0.00 ise oldukça düşük düzeyde bir ilişki olduğu ifade edilmiştir (Büyüköztürk, 2002, s.31-32). Algılanan müdür yönetim tarzı ile içsel motivasyonun örgütsel bağlılık üzerindeki etkisini bulmaya yönelik çoklu regresyon analizi yapılmıştır. Analizlerde anlamlılık düzeyi .05 olarak alınmıştır.

\section{BULGULAR}

\section{1. Öğretmenlerin algılanan müdür yönetim tarzı, içsel motivasyonu ve örgütsel bağlılıklarına ilişkin betimsel istatistik sonuçları}

Öğretmenlerin algılanan müdür yönetim tarzı, içsel motivasyonu ve örgütsel bağlılık alg1 düzeyinin betimsel istatistik bulguları Tablo 2'de belirtilmiştir.

Tablo 2. Öğretmenlerin algılanan müdür yönetim tarzı içsel motivasyonu ve örgütsel bağlılığına ilişkin betimsel istatistik sonuçları

\begin{tabular}{lcccc}
\hline Değişkenler & $\mathbf{N}$ & $\overline{\mathbf{x}}$ & $\mathbf{S S}$ & Madde Sayısı \\
\hline İşbirlikli & 391 & 4,38 & 0,69 & 7 \\
\hline Otoriter & 391 & 1,90 & 0,88 & 7 \\
\hline İlgisiz & 391 & 1,59 & 0,75 & 7 \\
\hline Karşı Koyucu & 391 & 1,49 & 0,68 & 4 \\
\hline İçel Motivasyon & 391 & 4,56 & 0,54 & 9 \\
\hline Örgütsel Bağlılık & 391 & 4,18 & 0,75 & 17 \\
\hline
\end{tabular}


Tablo 2 incelendiğinde katılımcıların algılanan işbirlikli müdür yönetim tarzı $(\overline{\mathrm{x}}=4,38)$ oldukça yüksek, otoriter müdür yönetim tarzı algı düzeyi ortalaması $(\overline{\mathrm{x}}=1,90)$ düşük, ilgisiz müdür yönetim tarzı algı düzeyi ortalaması $(\overline{\mathrm{x}}=1,59)$ oldukça düşük ve karşı koyucu müdür yönetim tarzı alg1 düzeyi ortalaması $(\overline{\mathrm{x}}=1,49)$ oldukça düşük düzeydedir. Bu bulguya göre öğretmenlerin işbirlilikli tarzı diğer yönetim tarzlarına göre daha olumlu gördükleri söylenebilir. Öğretmenlerin ilgisiz ve karşı koyucu müdür yönetim tarzını en olumsuz yönetici tarzı olarak algılamalarının sebebi, okul müdürleri tarafından yeterince destek görememe ve engellenme olduğu düşünülebilir. Araştırmada öğretmenlerin içsel motivasyon algı düzeyi ortalaması $(\overline{\mathrm{x}}=4,56)$ oldukça yüksek ve örgütsel bağlılığa ilişkin alg1 düzeyi ortalamasının ise $(\overline{\mathrm{x}}=4,18)$ yüksek düzeyde olduğu görülmüştür.

\section{2. Öğretmenlerin algılanan müdür yönetim tarzı, içsel motivasyonu ve örgütsel bağlılıklarına ilişkin nedensel karşılaştırma istatistik sonuçları}

Öğretmenlerin algılanan müdür yönetim tarzı, içsel motivasyonu ve örgütsel bağl1lık alg1 düzeyinin onların cinsiyet, branş ve kıdemlerine bağlı değişip değişmediğine ilişkin bulgular bu bölümde verilmiştir.

3.2.1. Cinsiyet-Öğretmenlerin algılanan müdür yönetim tarzı, içsel motivasyonu ve örgütsel bağl1lık algı düzeyinin onların cinsiyetlerine bağlı farklılık gösterip göstermediğine ilişkin $t$ testi bulguları Tablo 3'de belirtilmiştir.

Tablo 3. Cinsiyet değişkenine ilişkin istatistik sonuçları

\begin{tabular}{|c|c|c|c|c|c|c|c|}
\hline Değişkenler & Cinsiyet & $\mathbf{N}$ & $\overline{\mathbf{x}}$ & SS & sd & $\mathbf{t}$ & $\mathbf{p}$ \\
\hline \multirow{2}{*}{ İşbirlikli } & Erkek & 152 & 4,38 & ,66 & \multirow{2}{*}{389} & \multirow{2}{*}{0,087} & \multirow{2}{*}{,931 } \\
\hline & Kadın & 239 & 4,12 & ,69 & & & \\
\hline \multirow{2}{*}{ Otoriter } & Erkek & 152 & 1,99 & ,93 & \multirow{2}{*}{389} & \multirow{2}{*}{1,724} & \multirow{2}{*}{,086 } \\
\hline & Kadın & 239 & 1,83 & 84 & & & \\
\hline \multirow{2}{*}{ İlgisiz } & Erkek & 152 & 1,59 &, 78 & \multirow{2}{*}{389} & \multirow{2}{*}{0,203} & \multirow{2}{*}{839} \\
\hline & Kadın & 239 & 1,57 & ,73 & & & \\
\hline \multirow{2}{*}{ Karşı Koyucu } & Erkek & 152 & 1,5 & ,66 & \multirow{2}{*}{389} & \multirow{2}{*}{0,297} & \multirow{2}{*}{,767 } \\
\hline & Kadın & 239 & 1,47 & ,68 & & & \\
\hline \multirow{2}{*}{ İçsel Motivasyon } & Erkek & 152 & 4,48 &, 57 & \multirow{2}{*}{389} & \multirow{2}{*}{2,098} & \multirow{2}{*}{,037* } \\
\hline & Kadın & 239 & 4,6 &, 52 & & & \\
\hline \multirow{2}{*}{ Örgütsel Bağlllık } & Erkek & 152 & 4,25 & ,71 & \multirow{2}{*}{389} & \multirow{2}{*}{1,584} & \multirow{2}{*}{,114 } \\
\hline & Kadın & 239 & 4,12 &, 77 & & & \\
\hline
\end{tabular}

$\mathrm{p}<.05$

Tablo 3'te cinsiyet değişkenine göre öğretmenlerin algılanan işbirlikli, otoriter, ilgisiz, karş1 koyucu yönetim tarzı ve örgütsel bağl1lklarının benzer olduğu, ancak içsel motivasyonları algı düzeyinin erkek ve kadın öğretmenler arasında farklı olduğu [t(389)= -2,098; $\mathrm{p}<, 05]$ görülmektedir. Kadın öğretmenlerin $(\overline{\mathrm{x}}=4,60)$ erkek öğretmenlerden $(\overline{\mathrm{x}}=4,48)$ içsel motivasyon düzeyi daha yüksektir. $\mathrm{Bu}$ bulguya göre çalışmaya katılan öğretmenlerin, çalıştıkları okula karşı bağl1lıkları ile okul müdürlerinin yönetim tarzına ilişkin algılarının benzer olduğu, içsel motivasyon algılarının ise farklılık gösterdiği söylenebilir. Cinsiyet değişkeninin içsel motivasyon üzerinde etkisini belirlemek için etakare $\left(\eta^{2}\right)$ değerine bakılmıştır. Eta-kare değeri (.01) hesaplanmıştır. Bu bağlamda öğretmenlerin içsel motivasyon ölçeğinden aldıkları puanların toplam varyansın \% 1 ' inin onların cinsiyetlerine göre değiştiği söylenebilir. Hesaplanan $\left(\eta^{2}\right)$ değeri öğretmenlerin cinsiyetlerinin onların içsel motivasyonu üzerinde küçük düzeyde (Field, 2009, s.57) etkisinin olduğunu göstermektedir.

3.2.2. Branş-Öğretmenlerin algılanan müdür yönetim tarzı, içsel motivasyonu ve örgütsel bağlılığı algı düzeyinin onların branş göre değişip değişmediğine ilişkin $t$ testi bulguları Tablo 4'de belirtilmiştir.

Tablo 4. Branş değişkenine ilişkin istatistik sonuçları

\begin{tabular}{llcccccc}
\hline Değişkenler & Branş & $\mathbf{N}$ & $\overline{\mathbf{x}}$ & $\mathbf{S S}$ & $\mathbf{s d}$ & $\mathbf{t}$ & $\mathbf{p}$ \\
\hline \multirow{2}{*}{ İşbirlikli } & Okul Önc. ve Sınıf & 145 & 4,39 &, 78 & \multirow{2}{*}{389} & 0,265 & \multirow{2}{*}{, 791} \\
\cline { 2 - 7 } & Branş & 256 & 4,37 &, 62 & & & \\
\multirow{2}{*}{ Otoriter } & Okul Önc. ve Sınıf & 145 & 1,86 &, 87 & \multirow{2}{*}{389} & $-0,537$ & \multirow{2}{*}{, 592} \\
\cline { 2 - 7 } & Branş & 256 & 1,91 &, 89 & &
\end{tabular}




\begin{tabular}{|c|c|c|c|c|c|c|c|}
\hline \multirow{2}{*}{ İlgisiz } & Okul Önc. ve Sınıf & 145 & 1,70 & 84 & \multirow{2}{*}{389} & \multirow{2}{*}{2,316} & \multirow{2}{*}{, $021^{*}$} \\
\hline & Branş & 256 & 1,51 & ,68 & & & \\
\hline \multirow{2}{*}{ Karşı Koyucu } & Okul Önc. ve Sınıf & 145 & 1,51 & ,70 & \multirow{2}{*}{389} & \multirow{2}{*}{0,594} & \multirow{2}{*}{, 553} \\
\hline & Branş & 256 & 1,47 & ,66 & & & \\
\hline \multirow{2}{*}{ İçsel Motivasyon } & Okul Önc. ve Sınıf & 145 & 4,59 & ,54 & \multirow{2}{*}{389} & \multirow{2}{*}{1,054} & \multirow{2}{*}{,292 } \\
\hline & Branș & 256 & 4,53 &, 54 & & & \\
\hline \multirow{2}{*}{ Örgütsel Bağl1lık } & Okul Önc. ve Sınıf & 145 & 4,21 &, 76 & \multirow{2}{*}{389} & \multirow{2}{*}{0,726} & \multirow{2}{*}{,468 } \\
\hline & Branş & 256 & 4,15 & ,74 & & & \\
\hline
\end{tabular}

Tablo 4'de öğretmenlerin algılanan işbirlikli, otoriter, karşı koyucu müdür yönetim tarzları ile içsel motivasyon ve örgütsel bağl1lı̆̆ algı düzeyinin onların branşlarına göre anlamlı farklılık göstermediği, algılanan ilgisiz müdür yönetim tarzının ise branşları açısından anlamlı farklılaştığı $[\mathrm{t}(389)=2,316 ; \mathrm{p}<, 05]$ görülmektedir. Katılımcı öğretmenlerin ilgisiz müdür yönetim tarzına ilişkin algı düzeyi ortalamaları dikkate alındığında, okul öncesi ve sınıf öğretmenlerinin ilgisiz müdür yönetim tarz1 alg1 düzeyinin $(\overline{\mathrm{x}}=1,70)$ branş öğretmenlerine göre $(\overline{\mathrm{x}}=1,51)$ daha yüksek düzeyde olduğu anlaşılmaktadır. Bu bulguya göre, çalışmaya katılan okul öncesi ve sınıf öğretmenlerinin branş öğretmenlerine göre çalıştıkları okul müdürlerini daha ilgisiz tarzda yönetim sergileyen bir yönetici olarak düşündüklerini söylenebilir. Okul öncesi ve sınıf öğretmenlerinin branş öğretmenlerine göre okul müdürlerini daha ilgisiz yönetim tarzında görmelerinin sebebi, sınıf ile ilgili tüm sorumluluğu üzerlerinde hissetmeleri ve buna karş1lık müdürlerinden yeterli desteği göremediklerini düşünmeleri olabilir. Branş değişkeninin algılanan ilgisiz müdür yönetim tarzı üzerinde etkisini tespit etmek için $\left(\eta^{2}\right)$ değeri (.01) hesaplanmıştır. Katılımcıların ilgisiz müdür yönetim tarzı ölçeğinden aldıkları puanların toplam varyansın \% 1' inin branşlarına göre değiştiği söylenebilir. Hesaplanan $\left(\eta^{2}\right)$ değeri öğretmenlerin branşlarının algılanan ilgisiz müdür yönetim tarzı üzerinde küçük düzeyde (Field, 2009, s.57) etkisinin olduğunu göstermektedir.

3.2.3. Kıdem-Öğretmenlerin algılanan müdür yönetim tarzı, içsel motivasyonu ve örgütsel bağlılı̆̆ı algı düzeyinin çalışma sürelerine bağlı değişip değişmediğine ilişkin tek yönlü varyans analizi bulguları Tablo 5'de gösterilmiştir.

Tablo 5. Kıdem değişkenine ilişkin istatistik sonuçları

\begin{tabular}{|c|c|c|c|c|c|c|c|c|c|c|}
\hline Değişkenler & Kidem & $\mathbf{N}$ & $\overline{\mathbf{x}}$ & SS & & KT & SD & KO & $\mathbf{F}$ & $\mathbf{P}$ \\
\hline \multirow{4}{*}{ İşbirlikli } & $1-5$ y1l & 47 & 4,36 & 0,62 & $\begin{array}{l}\text { Gruplar } \\
\text { aras1 }\end{array}$ & 0,178 & 2 & 0,187 & \multirow{4}{*}{0,187} & \multirow{4}{*}{0,829} \\
\hline & 6-10 y1l & 83 & 4,42 & 0,65 & Grup içi & 184 & 388 & 0,474 & & \\
\hline & 11 ve üst & 261 & 4,37 & 0,7 & Toplam & 184,2 & 390 & & & \\
\hline & Toplam & 391 & 4,38 & 0,68 & & & & & & \\
\hline \multirow{4}{*}{ Otoriter } & $1-5$ y1l & 47 & 1,86 & 0,77 & $\begin{array}{l}\text { Gruplar } \\
\text { aras1 }\end{array}$ & 1,27 & 2 & 0,635 & \multirow{4}{*}{0,811} & \multirow{4}{*}{0,445} \\
\hline & 6-10 yıl & 83 & 1,8 & 0,84 & Grup içi & 303,8 & 388 & 0,783 & & \\
\hline & 11 ve üst & 261 & 1,93 & 0,91 & Toplam & 305,1 & 390 & & & \\
\hline & Toplam & 391 & 1,9 & 0,88 & & & & & & \\
\hline \multirow{4}{*}{ İlgisiz } & $1-5$ y1l & 47 & 1,68 & 0,84 & $\begin{array}{l}\text { Gruplar } \\
\text { aras1 }\end{array}$ & 0,97 & 2 & 0,485 & \multirow{4}{*}{0,854} & \multirow{4}{*}{0,427} \\
\hline & 6-10 y1l & 83 & 1,5 & 0,75 & Grup içi & 220,4 & 388 & 0,568 & & \\
\hline & 11 ve üst & 261 & 1,59 & 0,73 & Toplam & 221,4 & 390 & & & \\
\hline & Toplam & 391 & 1,58 & 0,75 & & & & & & \\
\hline \multirow{4}{*}{ Karşı Koyucu } & $1-5$ y1l & 47 & 1,62 & 0,73 & $\begin{array}{l}\text { Gruplar } \\
\text { aras1 }\end{array}$ & 1,182 & 2 & 0,591 & \multirow{4}{*}{1,287} & \multirow{4}{*}{0,277} \\
\hline & 6-10 yıl & 83 & 1,43 & 0,66 & Grup içi & 178,3 & 388 & 0,459 & & \\
\hline & 11 ve üst & 261 & 1,47 & 0,67 & Toplam & 179,4 & 390 & & & \\
\hline & Toplam & 391 & 1,48 & 0,67 & & & & & & \\
\hline \multirow{4}{*}{$\begin{array}{l}\text { İçsel } \\
\text { Motivasyon }\end{array}$} & $1-5$ yll & 47 & 4,56 & 0,5 & $\begin{array}{l}\text { Gruplar } \\
\text { aras1 }\end{array}$ & 0,046 & 2 & 0,023 & \multirow{4}{*}{0,077} & \multirow{4}{*}{0,926} \\
\hline & 6-10 yıl & 83 & 4,57 & 0,5 & Grup içi & 115,1 & 388 & 0,297 & & \\
\hline & 11 ve üst & 261 & 4,55 & 0,55 & Toplam & 115,1 & 390 & & & \\
\hline & Toplam & 391 & 4,55 & 0,54 & & & & & & \\
\hline
\end{tabular}




$\begin{array}{llccclcrrrr} & 1-5 \text { yıl } & 47 & 4,2 & 0,65 & \begin{array}{l}\text { Gruplar } \\ \text { aras1 }\end{array} & 0,919 & 2 & 0,46 & \\ \text { Örgütsel } & \text { 6-10 yıl } & 83 & 4,08 & 0,8 & \text { Grup içi } & 220,5 & 388 & 0,568 & 0,809 & 0,446 \\ \text { Bağl1l1k } & \text { 11 ve üst } & 261 & 4,2 & 0,75 & \text { Toplam } & 221,4 & 390 & & & \\ & \text { Toplam } & 391 & 4,17 & 0,75 & & & & & & \\ & & & & & & & & & \end{array}$

$\mathrm{p}<.05$

Tablo 5'de öğretmenlerin algılanan işbirlikli, otoriter, ilgisiz ve karşı koyucu müdür yönetim tarzı ile içsel motivasyonu ve örgütsel bağlılıkları algı düzeyinin kıdemlerine bağlı anlamlı farklılık göstermediği görülmüştür ( $\mathrm{p}>.05)$. Bu bağlamda çalışmaya katılan öğretmenlerin algıladıkları müdür yönetim tarzı, içsel motivasyonları ve örgütsel bağlılıklarının çalışma sürelerine bağlı değişmediği anlaşılmaktadır.

\section{3. Öğretmenlerin algılanan müdür yönetim tarzı, içsel motivasyonu ve örgütsel bağlılıklarına ilişkin regresyon analizi istatistik sonuçları}

Algılanan müdür yönetim tarzı ve içsel motivasyon değişkenlerinin öğretmenlerin örgütsel bağlılı̆ıını yordayıp yordamadığının anlaşılması için çoklu regresyon analizi sonuçları Tablo 6'da verilmiştir.

Tablo 6. Örgütsel bağl1lı̆̆ın yordanmasına ilişkin istatistik sonuçları

\begin{tabular}{llllllll}
\hline Yordanan Değişken Örgütsel Bağllık & & & & & \\
\hline Yordayıcı Değişken & $\mathrm{B}$ & $\mathrm{ShB}$ & $\beta$ & $\mathrm{T}$ & $\mathrm{p}$ & İkili r & Kısmi r \\
\hline Sabit & 1,376 &, 382 & & 3,601 &, 000 & & \\
\hline İşbirlikli &, 332 &, 057 &, 302 & 5,783 &, 000 &, 401 &, 283 \\
\hline Otoriter &, 014 &, 039 &, 017 &, 358 &, 721 &,- 034 &, 018 \\
\hline İlgisiz &, 038 &, 049 &, 038 &, 779 &, 437 &,- 116 &, 040 \\
\hline Karşı Koyucu &,- 110 &, 057 &,- 099 & $-1,921$ &, 055 &,- 230 &,- 097 \\
\hline İşsel Motivasyon & 313 &, 066 &, 226 & 4,709 &, 000 &, 331 &, 233 \\
\hline $\mathrm{R}=0,463$ & $\mathrm{R}=0,214$ & & & & & & \\
F= 20,953 & $\mathrm{P}=0,000$ & & & & & & \\
\hline
\end{tabular}

Tablo 6'da yordayıcı değişkenler (algılanan işbirlikli, otoriter, ilgisiz, karşı koyucu müdür yönetim tarzı ve içsel motivasyon) ile yordanan değişken (örgütsel bağlılık) arasındaki çoklu regresyon analiz bulguları görülmektedir. Tabloya göre, algılanan işbirlikli müdür yönetim tarzı ile öğretmenlerin örgütsel bağlılığının pozitif yönlü ve orta düzeyde $(\mathrm{r}=0,40)$, bunlar dışındaki değişkenlerin kontrol edildiğinde ise aralarındaki kısmi ilişkinin $(\mathrm{r}=0,28)$ olduğu anlaşılmıştır. Algılanan otoriter müdür yönetim tarzı ile öğretmenlerin örgütsel bağlılı̆̆ 1 arasında negatif yönlü ve düşük düzeyde $(\mathrm{r}=-0,03)$, bunlar dışındaki değişkenler kontrol edildiğinde arasındaki kısmi ilişkinin $(r=0,02)$ olduğu; algılanan ilgisiz müdür yönetim tarzı ile öğretmenlerin örgütsel bağlılı̆̆ının negatif yönlü ve düşük düzeyde ( $\mathrm{r}=-$ $0,11)$, diğer değişkenler kontrol edildiğide bunlar arasındaki kısmi ilişkinin $(\mathrm{r}=0,04)$ olduğu; algılanan karşı koyucu müdür yönetim tarzı ile öğretmenlerin örgütsel bağlıllğının negatif yönlü ve düşük düzeyde $(\mathrm{r}=-0,23)$, bunlar dışındaki değişkenlerin kontrol edildiğinde arasındaki kısmi ilişkinin $(\mathrm{r}=-$ $0,09)$ olduğu tespit edilmiştir. Yine öğretmenlerin içsel motivasyonu ve örgütsel bağl1lı̆̆ının pozitif yönlü ve orta düzeyde $(\mathrm{r}=0,33)$, aralarındaki kısmi ilişkinin ise $(\mathrm{r}=0,23)$ olduğu anlaşılmaktadır.

Çalışmaya katılan öğretmenlerin işbirlikli, otoriter, ilgisiz, karşı koyucu müdür yönetim tarzı ve içsel motivasyonu algı düzeyi ile örgütsel bağl1lık algı düzeyi arasında düşük düzeyde ve anlamlı ilişki olduğu tespit edilmiştir $\left(\mathrm{R}=0,463, \mathrm{R}^{2}=0,214, \mathrm{p}<.01\right)$. Buna göre, çalışmaya katılan öğretmenlerin algıladıkları işbirlikli, otoriter, ilgisiz, karşı koyucu müdür yönetim tarzı ve içsel motivasyon algı 
düzeyinin birlikte, onların örgütsel bağlılık alg1 düzeyi toplam varyansının \%21'ini açıkladığı görülmüştür.

Araştırmada bulgularına göre algılanan işbirlikli, otoriter, ilgisiz, karşı koyucu müdür yönetim tarzı ve içsel motivasyonun öğretmenlerin örgütsel bağl1lığındaki göreli önem sırası algılanan işbirlikli tarz, içsel motivasyon, ilgisiz tarz, otoriter tarz ve karşı koyucu tarz şeklindedir. Buna göre yordayıcı değişkenler arasında öğretmenlerin bağlılığını en çok algılanan işbirlikli müdür yönetim tarzının etkilediği anlaşılmaktadır. Ayrıca regresyon katsayılarının anlamlılığına bakıldığında, algılanan işbirlikli müdür yönetim tarzı ve içsel motivasyonun örgütsel bağlılık üzerinde önemli yordayıcılar olduğu, buna karşıllı algılanan otoriter, ilgisiz ve karşı koyucu müdür yönetim tarzlarının önemli etkisinin olmadığı görülmüştür. Bu bulguya göre, öğretmenlerin okula bağl1lıkları üzerinde içsel motivasyonları ile müdürlerinin işbirliğine yönelik davranış ve uygulamalarının etkili olduğu söylenebilir. Bu bağlamda öğretmenlerin okula bağlılıklarının sağlanması için içsel mativasyonlarını artırmaya ve okulda işbirliğini sağlamaya yönelik uygulamaların yaygınlaştırılması önemli görülmektedir.

\section{TARTIŞMA ve SONUÇ}

Araştırmada öğretmenlerin işbirlikli müdür yönetim tarzı alg1 düzeyinin oldukça yüksek, otoriter müdür yönetim tarzı algı düzeyinin düşük, ilgisiz ve karşı koyucu tarzı algı düzeyinin oldukça düşük olduğu görülmüştür. Literatürde yapılan çalışmalarda öğretmenlerin okul yöneticilerinin demokrat tarzda olduğunu düşündükleri (Terzi ve Kurt, 2005) ve en yüksek ortalamanın işbirlikli/demokratik yönetim tarzı iken otoriter, ilgisiz ve karşı koyucu müdür yönetim tarzı algı düzeyinin orta düzeyde (Özdemir vd., 2014) veya düşük düzeyinde (Argon ve Dilekçi, 2014) olduğu görülmektedir. Çalışmaya katılan ögretmenlerin, işbirlikli müdür yönetim tarzını diğer yönetim tarzına göre daha olumlu gördükleri bulgusu bu çalışmalar ile örtüşmektedir.

Öğretmenlerin motivasyon düzeyinin yüksek düzeyde olması, okulda eğitimde uygulanacak değişimlerin başarıyla gerçekleştirilmesini kolaylaştırabilir (Jesus ve Lens, 2005). Yapılan bu çalışmada da öğretmenlerin içsel motivasyon algı düzeyinin oldukça yüksek olduğu anlaşılmıştır. Literatürde öğretmenlerin içsel motivasyon algılarının yüksek düzeyde (Argon ve Ertürk, 2013; Özdemir ve diğerleri, 2014), iyi düzeyde (Tulunay Ateş, 2014) ve orta düzeyde (Memişoğlu ve Kalay, 2017) olduğuna ilişkin bulgular mevcuttur.

Araştırmaya katılan öğretmenlerin okula bağlılıklarına ilişkin algı düzeyinin yüksek düzeyde olduğu görülmüş̧ür. Literatürde örgütsel bağlllığın yüksek düzeyde (Bogler ve Somech, 2004; Karataş, ve Güleş, 2010; Tsui ve Cheng, 1999; Tulunay Ateş, 2014) ve orta düzeyde (Atik ve Üstüner, 2014; Çoban ve Demirtaş, 2011; Güçlü ve Zaman, 2011; Özgan, Yiğit ve Cinoğlu, 2011) tespit edildiği çalışmalar yer almaktadır. Bu bulgunun literatürde konu ile ilgili yapılan çalışmalarda elde edilen bulgularla örtüştüğü anlaşılmaktadır.

Çalışmaya katılan erkek ve kadın öğretmenlerin algılanan işbirlikli, otoriter, ilgisiz ve karşı koyucu müdür yönetim tarzı algılarının benzer olduğu bulgusu, literatürdeki bulgularla (Argon ve Dilekçi, 2014) desteklenmektedir. Başka bir araştırmada ise, çalışmaya katılan erkek öğretmenlerin okul müdürlerini otoriter ve ilgisiz buldukları ifade edilmektedir (Terzi ve Kurt, 2005). Araştırmaya katılan öğretmenlerin içsel motivasyona ilişkin algı düzeylerinde cinsiyetlerine göre anlamlı bir farklılık olduğu bulgusu, literatürde içsel motivasyonunun cinsiyete göre farkl1l1k gösterdiği bulgusu ile örtüşmektedir (Tulunay Ateş, 2014). Çalışmaya katılan kadın öğretmenlerin içsel motivasyonları erkek öğretmenlerden daha yüksektir.

Branş değişkenine göre, çalışmaya katılan öğretmenlerin algılanan işbirlikli, otoriter ve karş1 koyucu müdür yönetim tarzı algılarının benzer olduğu, buna karşılık ilgisiz müdür yönetim tarzı algılarının benzer olmadığı anlaşılmıştır. Literatürde yapılan bir çalışmada da sınıf ve branş öğretmenlerinin sadece otoriter yönetim tarzında algılarının benzer olduğu, bunun dışındaki yönetim tarzlarında sınıf öğretmenleri lehine birbirinden farklı düşüncelere sahip oldukları bulgusu elde edilmiştir (Argon ve Dilekçi, 2014). İçsel motivasyon algı düzeyinin öğretmenlerin branş değişkenine göre farklılık göstermediği bulgusu, literatürde öğretmenlerin motivasyon alg1 düzeyinin onların branşlarına göre benzer olduğu bulgusu ile desteklenmektedir (Recepoğlu, 2013). 
Araştırmada öğretmenlerin örgütsel bağl1lığa ilişkin algı düzeyi onların cinsiyetlerine, branş ve kıdemlerine göre benzer olduğu bulgusu, literatürde bu alanda yapılan çalışmalarla örtüşmektedir (Atik ve Üstüner, 2014; Memişoğlu ve Kalay, 2017).

Litrel, Billingsley ve Cross (1994), müdür desteğinin okula karşı bağl1lı̆̆ın bir belirleyicisi olduğunu belirtmişlerdir. Bu çalışmada da, algılanan işbirlikli müdür yönetim tarzı ile öğretmenlerin örgütsel bağlılığının ilişkili olduğu tespit edilmiştir. Öğretmenlerin okula bağlılıkları ile işbirlikli yönetim tarzının ilişkili olduğu bulgusu, litertürdeki çalışmalar (Hoy ve Tartar ve Bliss, 1990; Özdemir, 2012; Somech ve Bogler, 2002; Terzi ve Kurt, 2005; Yuen, 1991) ile desteklenmektedir. Araştırmada algılanan otoriter müdür yönetim tarzı, algılanan ilgisiz müdür yönetim tarzı ve algılanan karşı koyucu müdür yönetim tarzının öğretmenlerin örgütsel bağlılığı ile zıt yönlü ve düşük düzeyde ilişki bulunmuştur. Bu bulgu literatürde laissez-faire liderlik tarzı ile benzerlik göstermektedir (Buluç, 2009). Bu bağlamda okul müdürlerinin okulun yönetim faaliyetlerinde otoriter, ilgisiz ve karş1 koyucu yönetici tarzlarını kullanmalarının birlikte çalıştıkları öğretmenlerin okula bağlılıklarını azaltacağını söylenebilir.

Araştırmadaki bir diğer bulgu ise, öğretmenlerin içsel motivasyonu ile örgütsel bağl1lığının pozitif yönlü orta düzeyde ilişkili olduğudur. Buna göre elde edilen bulgu, literatürde motivasyon ile bağl1lığın pozitif yönlü ilişkili olduğunu destekleyen çalışmalarla örtüşmektedir (A ğca ve Ertan, 2008; Buluç, 2009; Farreil ve Rusbult, 1981 ve Stumpf ve Hartman, 1984 akt. Caldwell, Chatman ve O'Reilly, 1990; Kuavaas, 2006; Memişoğlu ve Kalay, 2017; Moon, 2000).

Müdür davranışlarının öğretmenlerin okula ilişkin memnuniyeti ve bağl11ı̆̆ üzerinde önemli bir etken olduğu düşünülmektedir (Anderman, Belzer ve Smith, 1991). Çalışmada öğretmenlerin algılanan işbirlikli, otoriter, ilgisiz ve karşı koyucu müdür yönetim tarzı ve içsel motivasyonu ile örgütsel bağl11ığının düşük düzeyde ve anlamlı ilişkisi tespit edilmiştir. Literatürde örgütsel bağl1lığın liderlik davranışlarıyla ilişkili olduğu, liderlik davranışlarının örgütsel bağlılı̆̆ın bir yordayıcısı olduğu, örgütsel bağl1lığın \%22'sinin liderlik davranışlarıyla açıklandığı ifade edilmektedir (Chiok Foong Loke, 2001). Bu çalışmada da, işbirlikli, otoriter, ilgisiz, karşı koyucu müdür yönetim tarzı ile içsel motivasyonun okula bağlılığın anlamlı yordayıcısı olduğu bulgusu elde edilmiştir. Özellikle algılanan işbirlikli müdür yönetim tarzının ve içsel motivasyonun örgütsel bağl1lık üzerinde önemli değişkenler olduğu, algılanan otoriter, ilgisiz ile karşı koyucu müdür yönetim tarzlarının ise önemli etkisinin olmadığı tespit edilmiştir. Bu değişkenlerin öğretmenlerin örgütsel bağlılığı üzerindeki göreli önem sırasının ise, işbirlikli müdür yönetim tarzı, içsel motivasyon, ilgisiz müdür yönetim tarzı, otoriter müdür yönetim tarzı ve son olarak karşı koyucu müdür yönetim tarzıdır. Araştırmanın bulgularına dayalı olarak şu öneriler geliştirilebilir:

- Öğretmenlerin okula duydukları bağlılıklarını güçlendirmek için, okul müdürlerinin okulun yönetim ve eğitim faaliyetlerinde öğretmenlerle işbirliği yapması, okulda yaşanan sorunlara onlarla birlikte çözüm yolları araması, okulda öğretmenleri ilgilendiren kararlarda onların görüşlerini alması gerektiği,

- Öğretmenlerin okula bağl1lıklarını artırmak için, okul müdürlerinin yönetimsel davranış ve uygulamalarında otoriter, ilgisiz ve karşı koyucu tarzdaki davranış ve uygulamalardan kaçınmaları,

- Öğretmenlerin birbirleriyle okul içinde ve dışında yapılan çalışmalarda işbirliği yapmalarının desteklenmesi,

- Öğretmenlerin okula bağl1lıklarını artırmak için onların içsel kaynaklı motive olmalarını destekleyecek uygulamaların gerçekleştirilmesi,

- Algılanan müdür yönetim tarzı ile öğretmenlerin örgütsel bağlılı̆̆ı ilişkisinde içsel motivasyonun aracı etkisinin incelendiği çalışmaların yapılması,

- Araştırmanın farklı ve daha büyük örneklem gruplarında tekrarlanması veya algılanan müdür yönetim tarzının ve içsel motivasyonun öğretmenlerin örgütsel bağlılığını nasıl etkilediğinin araştıııldığı nitel çalışmaların yapılması önerilebilir.

\section{KAYNAKLAR}

Ağca, V. ve Ertan, H. (2008). Duygusal bağllılı içsel motivasyon ilişkisi: Antalya'da beş yıldızlı otellerde bir inceleme. Afyon Kocatepe Üniversitesi İktisadi ve İdari Bilimler Dergisi, 10(2), 135-156. 
Alam, M. T., ve Farid, S. (2011). Factors affecting teachers motivation. International Journal of Business and Social Science, 2(1), 298-304.

Allen, N. J., ve Meyer, J. P. (1990). The measurement and antecedents of affective, continuance and normative commitment to the organization. Journal of Occupational Psychology, 63, 1-18.

Amabile, T. M. (1985). Motivation and creativity: Effects of motivational orientation on creative writers. Journal Of Personality and Social Psychology, 48(2), 393-399.

Anderman, E. M., Belzer, S. ve Smith, J. (1991). Teacher commitment and job satisfaction: The role of school culture and principal leadership. (Eric ED Number: ED 375 497).

Angle, H. L., ve Perry, J. L. (1981). An empirical assessment of organizational commitment and organizational effectiveness. Administrative Science Quarterly, 26(1), 1-14.

Argon, T., ve Dilekçi, Ü. (2014). Öğretmenlerin okul müdürlerinin yönetim tarzları ve kurumsal itibara yönelik algıları arasındaki ilişki. Electronic Turkish Studies, 9(2), 161-181.

Argon, T., \& Ertürk, R. (2013). İlköğretim okulu öğretmenlerinin içsel motivasyonları ve örgütsel kimliğe yönelik algıları. Kuram ve Uygulamada Ĕ̆itim Yönetimi, 2(2), 159-179.

Arıoğlu, E. (2006). Toplumsal değişimin dinamikleri. Ankara: Yeni Reform Yayıncılık

Atik, S., ve Üstüner, M. (2014). İlköğretim okullarının örgüt tipi ile öğretmenlerin örgütsel bağlılığı arasındaki ilişki. Ahi Evran Üniversitesi Kırşehir Eğitim Fakültesi Dergisi, 15(2), 133-154

Aydın, M. (2010). Ĕgitim Yönetimi. Ankara: Hatipoğlu Yayıncılık.

Aydın, M. (2013). Eğitimde örgütsel davranış. Ankara: Gazi Kitabevi.

Aydın, A., Sarıer, Y., ve Uysal, Ş. (2013). Okul müdürlerinin liderlik stillerinin, öğretmenlerin örgütsel bağlılığına ve iş doyumuna etkisi. Kuram ve Uygulamada Ĕ̆itim Bilimleri, 13(2), 795-811.

Balay, R. (2000). Özel ve resmi liselerde yönetici ve ögretmenlerin örgütsel bağlılı̆̆ (Ankara ili örneği). Yayınlanmamış doktora tezi, Ankara Üniversitesi, Sosyal Bilimler Enstitüsü, Ankara.

Balay, R. (2014). Yönetici ve ögretmenlerde: örgütsel bă̆lllık (İkinci baskı). Ankara: Pegem Akademi.

Başaran, İ. E. (1996). Eğitim Yönetimi (Beşinci baskı). Ankara: Yargıcı Matbaası.

Bateman, T. S., ve Strasser, S. (1984). A longitudinal analysis of the antecedents of organizational commitment. Academy of Management Journal, 27(1), 95-112.

Bogler, R., ve Somech, A. (2004). Influence of teacher empowerment on teachers' organizational commitment, professional commitment and organizational citizenship behavior in schools. Teaching and Teacher Education, 20(3), 277-289.

Brown-Howard, J. (2007). A study to determine the relationship between principal's leadership style and teacher motivation (Doctoral dissertation). Retrieved from ProQuest Dissertations and Thesis database. (UMI No. 3278085)

Buble, M., Juras, A., ve Matić, I. (2014). The relationship between managers' leadership styles and motivation. Management: Journal of Contemporary Management Issues, 19(1), 161-193.

Buchanan, B. (1974). Building organizational commitment: The socialization of managers in work organizations. Administrative Science Quarterly, 19(4), 533-546.

Buluç, B. (2009). Sınıf öğretmenlerinin algılarına göre okul müdürlerinin liderlik stilleri ile örgütsel bağl1lık arasındaki ilişki. Kuram ve Uygulamada Eğitim Yönetimi, 15(1), 5-34.

Bursalığlu, Z. (2005). Eğitim yönetiminde yeni yapı ve davranış. (Onüçüncü basım). Ankara: Pegem Akademi.

Bush, T. (2007). Educational leadership and management: Theory, policy and practice. South African Journal of Education, 27(3), 391-406.

Büyüköztürk, Ş. (2002). Faktör analizi: Temel kavramlar ve ölçek geliştirmede kullanımı. Kuram ve Uygulamada Ĕ̌itim Yönetimi, 8(4), 470-483.

Caldwell, D. F., Chatman, J. A. ve O'Reilly, C. A. (1990). Building organizational commitment: A multifirm study. Journal of Occupational Psychology, 63(3), 245-261.

Celep, C. (1998). Eğitim örgütlerinde öğretmenlerin örgütsel adanmışlı̆̆1. Eğitim ve Bilim, 22(108),56-62.

Celep, C. (2000). Ĕ̈itimde örgütsel adanma ve ögretmenler. Ankara: Anı Yayıncılık.

Cemaloğlu, N. (2002). Öğretmen performansının artırılmasında okul yöneticisinin rolü. Milli Ĕgitim Dergisi, 153(154), 153-154.

Chiok Foong Loke, J. (2001). Leadership behaviours: effects on job satisfaction, productivity and organizational commitment. Journal of Nursing Management, 9(4), 191-204.

Cook, J., ve Wall, T. (1980). New work attitude measures of trust, organizational commitment and personal need non-fulfilment. Journal of Occupational Psychology, 53(1), 39-52.

Çoban, D., ve Demirtaş, H. (2011). Okulların akademik iyimserlik düzeyi ile öğretmenlerin örgütsel bağlılığ1 arasındaki ilişki. Kuram ve Uygulamada Eğitim Yönetimi Dergisi, 17(3), 317-348.

Davis, J., ve Wilson, S. M. (2000). Principals' efforts to empower teachers: Effects on teacher motivation and job satisfaction and stress. The Clearing House: A Journal of Educational Strategies, Issues and Ideas, 73(6), 349-353.

Deci, E. L., Koestner, R., ve Ryan, R.M. (1999). A meta-analytic review of experiments examining the effects of extrinsic rewards on intrinsic. Psychological Bulletin, 125, 627-668. 
Deci, E. L., ve Ryan, R. M. (1985). Intrinsic motivation and self determination in human behavior. New York: Plenum.

Deci, E. L., Vallerand, R. J., Pelletier, L. G., ve Ryan, R. M. (1991). Motivation and education: The selfdetermination perspective. Educational psychologist, 26(3-4), 325-346.

Demirtaş, H., Özer, N., Atik, S., ve Kırbaç, M. (2015). Sendikal vatandaşlık davranışı ve sendikal kimlik ilişkisi: öğretmenler üzerine bir araştırma. Trakya Üniversitesi Eğitim Fakültesi Dergisi, 5(2), 77-93.

Dündar, S., Özutku, H., ve Taşpınar, F. (2007). İçsel ve dışsal motivasyon araçlarının işgörenlerin motivasyonları üzerindeki etkisi: Ampirik bir inceleme. Ticaret ve Turizm Eğitim Fakültesi Dergisi, 2, 107-108.

Eby, L. T., Freeman, D. M., Rush, M. C., ve Lance, C. E. (1999). Motivational bases of affective organizational commitment: A partial test of an integrative theoretical model. Journal Of Occupational And Organizational Psychology, 72(4), 463-483.

Eisenberg, E. M., Monge, P. R., ve Miller, K. I. (1983). Involvement in communication networks as a predictor of organizational commitment. Human Communication Research, 10(2), 179-201.

Erdoğan, İ. (2014). Ĕ̌itim ve okul yönetimi. İstanbul: Alfa Yayınları.

Eyal, O., ve Roth, G. (2011). Principals' leadership and teachers' motivation: Self-determination theory analysis. Journal of Educational Administration, 49(3), 256-275.

Field, A. (2009). Discovering statistics using SPSS (3rd ed.). London, England: Sage Publications.

Firestone, W. A., ve Pennell, J. R. (1993). Teacher commitment, working conditions, and differential incentive policies. Review of Educational Research, 63(4), 489-525.

Firestone, W. A., ve Rosenblum, S. (1988). Building commitment in urban high schools. Educational Evaluation and Policy Analysis, 10(4), 285-299.

Fraenkel, J. R., Wallen, N. E. ve Hyun, H. H. (2012). How to Design and Evaluate Research in Education (8th edt.). New York: McGram-Hill Companies.

Güçlü, N., ve Zaman, O. (2011). Alan dışından atanmış rehber öğretmenlerin iş doyumları ile örgütsel bağlılıkları arasındaki ilişki. Türk Ĕ̆itim Bilimleri Dergisi, 9(3), 541-576.

Gül, İ., ve Saraç, G. (2018). Okul Müdürlerinin Demokratik Tutumları. Uluslararası Sosyal ve Eğitim Bilimleri Dergisi, 5(10), 155-172.

Gülcan, M. G. (2012). Research instructional leadership competencies of school principals. Education,132(3), $625-635$.

Hallinger, P. (2005). Instructional leadership and the school principal: A passing fancy that refuses to fade away. Leadership and Policy in Schools, 4(3), 221-239.

Hulpia, H., Devos, G., ve Keer, H. V. (2010). The influence of distributed leadership on teachers' organizational commitment: A multilevel approach. The Journal of Educational Research, 103, 40-52.

Hoy, W., ve Miskel, C.G. (2012). Eğitim yönetimi teori, araştırma ve uygulama (S.Turan, Çev.). Ankara: Nobel Akademik Yayıncılik.

Hoy, W. K., Tartar, C. J., ve Bliss, J. R. (1990). Organizational climate, school health, and effectiveness: A comparative analysis. Educational Administration Quarterly, 25(3), 260-279.

Jesus, S. N., ve Lens, W. (2005). An integrated model for the study of teacher motivation. Applied Psychology: An International Review, 54(1), 119-134.

Kanter, R. M. (1968). Commitment and social organization: A study of commitment mechanisms in utopian communities. American Sociological Review, 33(4), 499-517.

Karasar, N. (2012). Bilimsel araştırma yöntemi. Ankara: Nobel Yayın Dağıtım.

Karataş, S., ve Güleş, H. (2010). İlköğretim okulu öğretmenlerinin iş tatmini ile örgütsel bağlılığı arasındaki ilişki. Uşak Üniversitesi Sosyal Bilimler Dergisi, 3(2), 74-89.

Klassen, R. M., Chong, W. H., Huan, V. S., Wong, I., Kates, A. ve Hannok, W. (2008). Motivation beliefs of secondary school teachers in Canada and Singapore: A mixed methods study. Teaching and Teacher Education, 24, 1919-1934

Kuvaas, B. (2006). Work performance, affective commitment, and work motivation: The roles of pay administration and pay level. Journal of Organizational Behavior: The International Journal of Industrial, Occupational and Organizational Psychology and Behavior, 27(3), 365-385.

Littrell, P., Billingsley, B., \& Cross, L. (1994). The effects of support on general and special educators' stress, job satisfaction, health, commitment, and intent to stay in teaching. Remedial and Special Education, 15(5), 297-310.

Leithwood, K., ve Jantzi, D. (2006). Transformational school leadership for large-scale reform: Effects on students, teachers, and their classroom practices. School Effectiveness and School Improvement, 17(2), 201-227.

Leithwood, K., ve Mascall, B. (2008). Collective leadership effects on student achievement. Educational Administration Quarterly, 44(4), 529-561.

Lok, P., ve Crawford, J. (1999). The relationship between commitment and organizational culture, subculture, leadership style and job satisfaction in organizational change and development. Leadership \& Organization Development Journal, 20(7), 365-374.

Lunenburg, F. C., ve Ornstein, A. C. (2013). Eğitim Yönetimi (Çev. G. Arastaman). Ankara: Nobel Yayın Dağıtım. 
Memişoğlu, S. P., ve Kalay, M. (2017). İlkokul ve ortaokullarda görev yapan öğretmenlerin örgütsel bağl1lık ve motivasyonları arasındaki ilişki (Bolu ili örneği). Electronic Turkish Studies, 12(4), 367-392.

Meyer, J.P., ve Allen, N. J. (1991). A three-component conceptualization of organizational Commitment. Human Resource Management Review, 1(1), 61-89.

Meyer, J. P., Becker, T. E., ve Vandenberghe, C. (2004). Employee commitment and motivation: a conceptual analysis and integrative model. Journal of Applied Psychology, 89(6), 991-1007.

Moon, M. J. (2000). Organizational commitment revisited in new public management: Motivation, organizational culture, sector, and managerial level. Public Performance \& Management Review, 24(2), 177-194.

Morrow, P. C. (1983). Concept redundancy in organizational research: The case of work commitment. Academy of Management Review, 8(3), 486-500.

Mowday, R. T., Steers, R. M., ve Porter, L. W. (1979). The measurement of organizational commitment. Journal of Vocational Behavior, 14(2), 224-247.

Okçu, V. (2014). Ortaöğretim okulu yöneticilerinin etik liderlik davranışları ile öğretmenlerin örgütsel bağl1lıkları arasındaki ilişki. Kuram ve Uygulamada Ĕ̆itim Yönetimi Dergisi, 20(4), 501-524.

O'Reilly, C. A. ve Chatman, J. (1986). Organizational commitment and psychological attachment: The effects of compliance, identification, and internalization on prosocial behavior. Journal of Applied Psychology, 71(3), 492.

Özdemir, A. (2012). İlköğretim okul müdürlerinin demokratik tutumlarının öğretmenlerin örgütsel băglılık alglsı ile ilişkisi (İstanbul İli Sancaktepe-Çekmeköy İlçeleri), Yayınlanmamış yüksek lisans tezi, Yeditepe Üniversitesi, İstanbul.

Özdemir, T. Y., Kartal, S. E., ve Yirci, R. (2014). Okul Müdürlerinin Öğretmenleri Motive Etme Yaklaşımları. Turkish Journal of Educational Studies, 1(2), 190-215.

Özden, Y. (1997). Öğretmenlerde okula adanmışlık: Yönetici davranışlarıyla ilişkili mi? Milli Eğitim Dergisi, 135, $35-41$.

Özgan, H., Yiğit, C. ve Cinoğlu, M. (2011). İlköğretim okulu öğretmenlerinin örgütsel bağlılık düzeylerinin incelenmesi. KSÜ Sosyal Bilimler Dergisi, 8(1), 1-14.

Price, A. M. (2008). The relationship between the teacher's perception of the principal's leadership style and personal motivation (Doctoral dissertation). Retrieved from ProQuest Dissertations and Thesis database. (UMI No. 3346553)

Porter, L. W., Steers, R. M., Mowday, R. T., ve Boulian, P. V. (1974). Organizational commitment, job satisfaction, and turnover among psychiatric technicians. Journal of applied psychology, 59(5), 603-609. (ERIC ED NO: CB 002 562).

Recepoğlu, E. (2013). Öğretmen adaylarının yaşam doyumları ile öğretmenlik mesleğine ilişkin tutumları arasındaki ilişkinin incelenmesi. Hacettepe Üniversitesi Ĕ̆itim Fakültesi Dergisi, Özel, (1), 311-326.

Reynolds, C. L. (2009). Transformational leadership and teacher motivation in Southwestern Arizona high schools (Doctoral dissertation). Retrieved from ProQuest Dissertations and Thesis database. (UMI No. $3366300)$.

Riggio, R.E. (2016). Endüstri ve örgüt psikolojisine giriş (B. Özkara, Çev.). Ankara: Nobel Akademik Yayıncılık.

Robbins, S.P., ve Judge, T.A. (2013). Örgütsel davranış (İ. Erdem, Çev. Ed.). Ankara: Nobel Akademik Yayıncilik

Rosenholtz, S. J. (1989). Workplace conditions that affect teacher quality and commitment: Implications for teacher induction programs. The Elementary School Journal, 89(4), 421-439.

Ryan, R. M., ve Deci, E. L. (2000). Intrinsic and extrinsic motivations: Classic definitions and new directions. Contemporary Educational Psychology, 25(1), 54-67.

Sarı, M., Yıldız, E., ve Canoğulları, E. (2018). Öğretmenlerin Algıladıkları Müdür Yönetim Tarzı ile Mesleki Motivasyon Düzeyleri Arasındaki İlişki. Uluslararası Sosyal ve Eğitim Bilimleri Dergisi, 5(10), 188208.

Scholl, R. W. (1981). Differentiating organizational commitment from expectancy as a motivating force. Academy of Management Review, 6(4), 589-599.

Somech, A.,ve Bogler, R. (2002). Antecedents and consequences of teacher organizational and professional commitment. Educational Administration Quarterly, 38(4), 555-577.

Staw, B. M., ve Ross, J. (1978). Commitment to a policy decision: A multi-theoretical perspective. Administrative Science Quarterly, 23(1), 40-64.

Steers, R. M., Mowday, R. T., ve Shapiro, D. L. (2004). The future of work motivation theory. Academy of Management Review, 29(3), 379-387.

Sun, J. (2004). Understanding the impact of perceived principal leadership style on teacher commitment. International Studies in Educational Administration, 32(2), 18-31.

Supovitz, J., Sirinides, P. ve May, H. (2010). How principals and peers influence teaching and learning. Educational Administration Quarterly, 46(1), 31-56

Şişman, M., ve Turan, S. (2005). Eğitim ve okul yönetimi. Y. Özden (Ed.) (2005). Eğitim ve okul yöneticiliği el kitabı. (99-146) İçinde. Ankara: Pegema Yayınları. 
Taymaz, H. (2011). İlköğretim ve ortaöğretim okul müdürleri için okul yönetimi. (10. Baskı). Ankara: Pegem Akademi.

Terzi, A. R., ve Kurt, T. (2005). İlköğretim okulu müdürlerinin yöneticilik davranışlarının öğretmenlerin örgütsel bağlılığına etkisi. Milli Ĕ̆itim Dergisi, 33(166), 98-112.

Thoonen, E. E., Sleegers, P. J., Oort, F. J., Peetsma, T. T., ve Geijsel, F. P. (2011). How to improve teaching practices: The role of teacher motivation, organizational factors, and leadership practices. Educational Administration Quarterly, 47(3), 496-536.

Tsui, K. T., ve Cheng, Y. C. (1999). School organizational health and teacher commitment: A contingency study with multi-level analysis. Educational Research and Evaluation, 5(3), 249-268.

Tulunay Ateş, Ö. (2014). Illköğretim okullarında görev yapan öğretmenlerin duygusal zeka, motivasyon ve örgütsel bağlılıkları arasındaki ilişki. Yayımlanmamış doktora tezi. Gazi Üniversitesi, Eğitim Bilimleri Enstitüsü, Ankara.

Türk Dil Kurumu (2018). Yabancl sözlere karşılıklar kılavuzu. http://tdk.gov.tr/index.php?option=com_karsilik\&view=karsilik\&kategori1=karsilik_liste\&ayn1=bas\& kelime1=motivasyon. 25/11/2018 tarihinde erişim sağland 1 .

Uğurlu, C. T., Beycioğlu, K., ve Özer, N. (2011). Okul müdürlerin eğitim öğretim etkinliklerine yönelik liderlik davranışları, 6. Ulusal Eğitim Yönetimi Kongresi, 16-17 Nisan, KKTC: Eğitim Yöneticileri ve Deneticileri Derneği.

Uslu, B., ve Beycioğlu, K. (2013). İlköğretim okulu öğretmenlerinin örgütsel bağl1lıkları ile müdürlerin paylaşılan liderlik rolleri arasındaki ilişki. Ondokuz Mayıs Üniversitesi Ĕ̆itim Fakültesi Dergisi, 32(2), 323-345.

Üstüner, M. (2009). Öğretmenler için örgütsel bağl1lık ölçeği: geçerlik ve güvenirlik çalışması. İnönü Üniversitesi Ĕ̈itim Fakültesi Dergisi, 10(1), 1-17.

Üstüner, M. (2016). Algılanan Müdür Yönetim Tarzı Ölçeğinin Geçerlik ve Güvenirlik Çalışması. Kuram ve Uygulamada Ĕ̈itim Yönetimi Dergisi, 22(3), 429-457.

Vallerand, R. J., Pelletier, L. G., Blais, M. R., Brière, N. M., Senécal, C. B., ve Vallières, E. F. (1992). The academic motivation scale: A measure of intrinsic, extrinsic, and amotivation in education. Educational and Psychological Measurement, 52, 1003-1017.

Webb, S. R. (2007). The relationship between elementary school principals' leadership approaches and teacher motivation and job satisfaction in Alabama's Black Belt Region (Doctoral dissertation). Retrieved from ProQuest Dissertations and Thesis database. (UMI No. 3292149)

Woolfolk Hoy, A. (2008). What motivates teachers? Important work on a complex question. Learning and Instruction, 18, 492-498.

Yılmaz, A., ve Ceylan, Ç.B. (2011). İlköğretim okul yöneticilerinin liderlik davranış düzeyleri ile öğretmenlerin iş doyumu ilişkisi. Kuram ve Uygulamada Ĕ̆itim Yönetimi, 17(2), 277-394.

Yousef, D. A. (2000). Organizational commitment: Amediator of the relationships of leadership behavior with job satisfaction and performance in a non-Western country. Journal of Managerial Psychology, 15, 6-23.

Yu, H., Leithwood, K., ve Jantzi, D. (2002). The effects of transformational leadership on teachers' commitment to change in Hong Kong. Journal of educational administration, 40(4), 368-389.

Yuen, P., Y. (1991). "Principal leadership behavior and teacher organizational commitment- a contigency approach." Master Arts in Education Thesis. http://www.fed.cuhk.edu.hk/ceric/cuma/91pyyuen/conclusion.html, 25/11/2018 tarihinde erişim sağlandi.

Zel, U. (2001). Kişilik ve liderlik (1. Baskı). Ankara: Seçkin Yayınları. 